\title{
Demography of the largest and most endangered Brazilian parrotfish, Scarus trispinosus, reveals overfishing
}

\author{
Natalia C. Roos $^{1, *}$, Brett M. Taylor ${ }^{2}$, Adriana R. Carvalho ${ }^{3}$, Guilherme O. Longo ${ }^{1}$ \\ ${ }^{1}$ Marine Ecology Laboratory, Department of Oceanography and Limnology, \\ Universidade Federal do Rio Grande do Norte, Natal, RN, 59014-002, Brazil \\ ${ }^{2}$ The Australian Institute of Marine Science, Crawley, WA 6008, Australia \\ ${ }^{3}$ Fishing Ecology, Management and Economics group, Department of Ecology, \\ Universidade Federal do Rio Grande do Norte, Natal, RN, 59098-970, Brazil
}

\begin{abstract}
Many parrotfishes (Labridae: Scarinae) have life history traits, including late maturation and long lifespans, that make them vulnerable to overfishing. The greenbeak parrotfish Scarus trispinosus is the largest Brazilian endemic parrotfish and has been harvested in reefassociated fisheries along the coast. After a sharp population decline, S. trispinosus is now considered by the IUCN to be an Endangered species. We provide an assessment of age-based and reproductive biology for this species and discuss applications for fisheries management. We sampled 95 individuals from inshore and offshore reefs from Rio Grande do Norte state, northeast Brazil, both obtained from artisanal fishing landings and fishery-independent collections. All sampled specimens were females with fork lengths (FL) ranging from 8.1 to $55.9 \mathrm{~cm}$ and ages ranging from 0.3 to $7 \mathrm{yr}$, with estimated median maturity $\left(L_{50}\right)$ of $39.2 \mathrm{~cm}$ FL and median age $\left(A_{50}\right)$ of $4.2 \mathrm{yr}$. Size class distributions indicate that the inshore reefs are mostly inhabited by juveniles under $L_{50}$, whereas the offshore reefs are inhabited by mature individuals, suggesting an ontogenetic habitat shift from inshore to offshore reefs around the timing of maturation. The fishing pressure on this species is concentrated in inshore reefs, therefore mostly on immature individuals, which may be severely affecting the reproductive capacity of this species. This information is useful to guide size-based fisheries management, such as regulating minimum capture size and fishing gears that capture individuals smaller than $L_{50}$. Managing fisheries of endangered species with late maturity and complex reproductive cycles such as $S$. trispinosus is imperative to aid recovery.
\end{abstract}

KEY WORDS: Life history $\cdot$ Endemic $\cdot$ Fisheries management $\cdot$ Reproduction $\cdot$ Southwestern Atlantic

\section{INTRODUCTION}

Parrotfishes (Labridae: Scarinae) are important for subsistence and commercial reef fisheries worldwide. However, increased fishing pressure on this group in recent decades is leading to population declines in many regions (Hawkins \& Roberts 2004b, Aswani \& Sabetian 2010, Comeros-Raynal et al. 2012,

${ }^{*}$ Corresponding author: nataliaroos@gmail.com
Bender et al. 2014, Hamilton et al. 2016). Because parrotfishes perform important ecological roles in reef ecosystems, such as grazing and bioerosion (Bellwood \& Choat 1990, Bonaldo et al. 2014), the consequences of parrotfish harvesting have been widely investigated and discussed (e.g. Mumby 2006, Lokrantz et al. 2010, Bellwood et al. 2012, Bozec et al. 2016). Besides their ecological importance, parrot-

() The authors 2020. Open Access under Creative Commons by Attribution Licence. Use, distribution and reproduction are unrestricted. Authors and original publication must be credited. 
fishes are also known for having a diverse and complex range of reproductive strategies (Taylor et al. 2018). Life-history traits such as life span, growth, size and age at maturity, and rates of mortality and maturation directly affect population dynamics, and are thus critical to comparatively infer species vulnerability to overexploitation (Taylor et al. 2014). Such information is often scarce, hampering the implementation of appropriate management policies to protect parrotfishes from overfishing.

For parrotfishes, susceptibility to overfishing stems from several characteristics, including their relatively large body size and ubiquitous occurrence in shallow depths (Bonaldo et al. 2014, Taylor et al. 2014). In addition to reducing the abundance of parrotfishes in absolute numbers, fishing pressure may also affect population structure by reducing the average size of individuals and induce species to change sex at smaller sizes (Hawkins \& Roberts 2004a, Kindsvater et al. 2017). The sex change is an important issue, since most parrotfish species are protogynous hermaphrodites (i.e. females change sex to males); some species are monandric, where all males derive from functionally mature females (i.e. secondary males); and some are diandric, where 2 types of males are present in the population: those that are males at the first sexual maturation (i.e. primary males) and those that are derived from functional females (i.e. secondary males; Sadovy de Mitcheson \& Liu 2008). In some species, however, males develop before female maturation, which means they are not functionally protogynous (Hamilton et al. 2008). If fishing pressure is too high upon small size classes, fewer individuals survive long enough to reach maturation and reproduce. This could be a critical issue for a relatively long-lived, late-maturing parrotfish species.

In Brazil, parrotfishes are targeted along the coast mostly by small-scale fisheries (Francini-Filho \& Moura 2008, Bender et al. 2014, Roos et al. 2016). Some species have shown signs of decline, especially the endemic greenbeak parrotfish Scarus trispinosus. The species is the largest parrotfish in the southwestern Atlantic and occurs along almost the entire Brazilian coast, although it is more common in warmer waters, and has been intensively targeted by fisheries in 2 areas encompassing its largest remnant populations: the Abrolhos Bank (Francini-Filho \& Moura 2008) and in the coastal reef of Rio Grande do Norte state (Roos et al. 2016). Large individuals ( $>40 \mathrm{~cm}$ total length, TL) tend to use more offshore reefs, while juveniles are more common in coastal reefs (Roos et al. 2019), where artisanal fisheries tend to be more intense. After a sharp population decline over the last 3 decades, $S$. trispinosus is listed as Endangered by the IUCN (Padovani-Ferreira et al. 2012) and by the Brazilian Red List of Endangered Species (Ministerio do Meio Ambiente Decree No. 445 of 2014). In some areas, $S$. trispinosus is even considered ecologically extinct based on how rare it has become (Floeter et al. 2007, Bender et al. 2014). However, information on the life-history traits of this species that are critical to fisheries management and conservation, including growth, size and age at maturity, is still scarce (but see Freitas et al. 2019) or unknown, such as size and age at sex change, thus perpetuating the threat to this species.

Here we provide information on age, growth, and reproductive maturation of $S$. trispinosus in the second-most important fishing area of this species, the state of Rio Grande do Norte in northeast Brazil (Roos et al. 2016). In particular, we highlight differences between the population structure of inshore and offshore reefs, and the need for incorporating this information into fisheries management actions.

\section{MATERIALS AND METHODS}

\subsection{Sampling locations}

Samples were obtained in the state of Rio Grande do Norte, northeast Brazil (between $4^{\circ} 00^{\prime} \mathrm{S}, 37^{\circ} 00^{\prime} \mathrm{W}$ and $7^{\circ} 00^{\prime} \mathrm{S}, 34^{\circ} 00^{\prime} \mathrm{W}$; Fig. 1). This region comprises the second-largest catch of Scarus trispinosus in Brazil, where a single village of small-scale fishers, among others that also fish for this species, harvests up to $9 \mathrm{t}$ every year from a $\sim 20 \mathrm{~km}^{2}$ shallow reef area (Roos et al. 2016). The region harbors heterogeneous reef habitats in terms of geomorphological features and benthic cover (Roos et al. 2019, Rovira et al. 2019). It includes offshore reefs located $\sim 22 \mathrm{~km}$ from the northern coast in which depths vary from 6 to $60 \mathrm{~m}$ and which are mainly covered by coralline algae and Dictyota spp.; and nearshore shallower patchy reefs located $\sim 7 \mathrm{~km}$ from the eastern coast in which depths vary from 1 to $6 \mathrm{~m}$, and which are mainly covered by stony corals, zoanthids, coralline algae, and Dictyota spp. (Fig. 1; see Roos et al. 2019 for a detailed description of sites). Both areas contain relatively high abundances of $S$. trispinosus; however, they differ in total abundance and size class distribution. While offshore reefs sustain considerably higher biomass due to the higher abundance of large-sized individuals, inshore reefs harbor mostly recruits and small juveniles (Roos et al. 2019). 


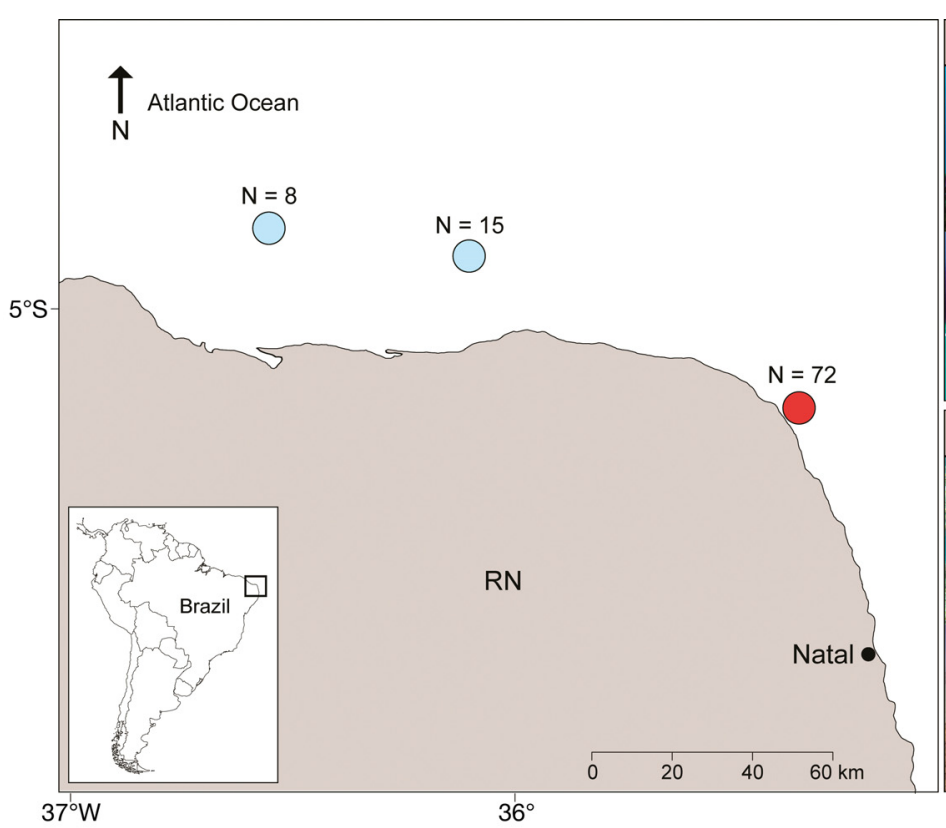

\subsection{Sampling effort}

A total of 95 specimens of $S$. trispinosus were sampled between July 2016 and March 2018; of these, 23 individuals were collected through scientific spearfishing at offshore reefs on the northern coast in depths between 8 and $12 \mathrm{~m}$, and 68 were obtained through samplings at a fish market located on the eastern coast, where local fishers use inshore shallow patchy reefs to fish parrotfishes (see details in Roos et al. 2016). Lastly, 4 smaller individuals (between 8.1 and $19.3 \mathrm{~cm}$ ) were collected through research spearfishing at the inshore reefs. Parrotfish fishing occurs mainly between November and April in the shallow patchy reefs, when the wind speed is lower and water visibility inshore is better (Roos et al. 2016). In contrast, the offshore reefs of the northern coast can only be accessed between July and October due to the favorable wave conditions in this period. All sampling was carried out under permit SISBIO-51402-1.

Fork length (FL), TL, and total weight (TW) of all individuals were recorded to the nearest $\mathrm{mm}$ and $\mathrm{g}$. It was not possible to get TWs for 10 individuals obtained in the fish market because they were already eviscerated. Whole gonads were also weighed to the nearest $\mathrm{g}$ and fixed in $10 \%$ formalin buffered with sodium phosphate monobasic $\left(\mathrm{NaH}_{2} \mathrm{PO}_{4} \mathrm{H}_{2} \mathrm{O}\right)$ and dibasic $\left(\mathrm{Na}_{2} \mathrm{H}_{2} \mathrm{PO}_{4}\right)$ to ensure the adequate preservation of the oocytes. Sagittal otoliths were removed, cleaned, and stored dry. Samples from inshore and offshore reefs were combined for age, growth, and reproductive analysis.

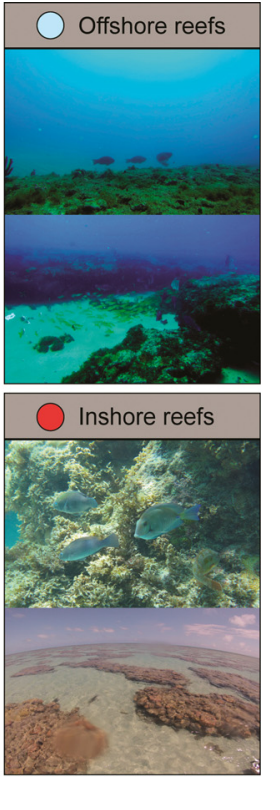

Fig. 1. Study area, indicating the number of samples collected in each location

\subsection{Age, growth, and mortality}

One sagittal otolith from each specimen's pair was randomly selected for age analysis $(\mathrm{N}=80)$. Otoliths were weighed to the nearest $0.0001 \mathrm{~g}$ and mounted on the edge of a glass slide using thermoplastic glue with the primordium situated just inside the slide edge. The otolith material was sanded away using a 600 -grit diamond lapping wheel with continuous water flow. The slide was reheated at $200^{\circ} \mathrm{C}$ and the otolith was remounted with the newly sectioned surface face down. The remaining material was sanded away until a thin $(\sim 200 \mu \mathrm{m})$ transverse cross-section of the otolith core remained. Finally, sectioned otoliths were reheated and covered with thermoplastic glue to enhance clarity of the annual rings. Annual rings (annuli) were counted twice on 2 separate occasions by a single reader (B.M.T.). When the 2 age estimates differed, a third read was conducted. Age in years was assigned when 2 age assignments agreed, which occurred for all specimens. Annual periodicity of rings was not directly measured in this study, but was presumed based on banding patterns highly consistent with validated parrotfish species (Choat et al. 2009, Taylor et al. 2018). Daily rings were enumerated for the smallest individual after successive polishing of the otolith face using 9, 3, and $0.3 \mu \mathrm{m}$ lapping film. Growth was examined using length-at-age data fitted with the von Bertalanffy growth function:

$$
L_{t}=L_{\infty}\left[1-\mathrm{e}^{-k\left(t-t_{0}\right)}\right]
$$

where $L_{t}$ is the predicted mean FL $(\mathrm{cm})$ at age $t(\mathrm{yr})$, $L_{\infty}$ is the asymptotic $\mathrm{FL}, k$ is the coefficient used to 
describe the curvature of fish growth towards $L_{\infty}$, and $t_{0}$ is the hypothetical age at which FL $=0$, as described by $k$.

The instantaneous rate of total mortality $\left(Z, \mathrm{yr}^{-1}\right)$ was estimated through the age frequency distribution of the inshore population (i.e. considering a maximum observed age of 6 yr), given that samples come mostly from inshore reefs and the species migrates offshore ontogenetically. Hence, $Z$ reflects both total mortality in addition to emigration rate through ontogenetic movements across habitats. $Z$ was calculated as the absolute value of the slope of a line fitted to the natural logarithm of observed frequency for those age classes that are fully recruited into the fishery (Beverton \& Holt 1957).

\subsection{Reproduction}

Sampled gonads were dehydrated in alcohol, cleared in xylol, embedded in paraffin blocks, sectioned at $5 \mu \mathrm{m}$, and stained with hematoxylin and eosin. Sex assignment and maturity staging were done from histological sections of gonads using the standardized terminology of Brown-Peterson et al. (2011). Length and age at $50 \%$ sexual maturity $\left(L_{50}\right.$ and $A_{50}$, respectively) were estimated by the proportional frequencies of immature and mature females, fitted with a logistic curve:

$$
P_{i}=G\left(1+\mathrm{e}^{(-r(X i-C))}\right)^{-1}
$$

where $P_{i}$ is the proportion or ratio of reproductive females at length or age $X_{i}$; $G$ is the curve asymptote; $r$ is a rate parameter related to the speed of size/age change from non-reproductive to reproductive status; and $C$ is the $L_{50}(\mathrm{~cm})$ or $A_{50}(\mathrm{yr})$. Curves were fitted by minimizing the binomial maximum likelihood, and corresponding 95\% confidence intervals were derived by bootstrap resampling through 1000 iterations.

All analyses were performed in $\mathrm{R}$ version 3.2.3 ( $\mathrm{R}$ Development Core Team 2015; www.R-project.org) and using the packages 'ggplot2' (Wickham 2016) and 'FSA' (Ogle et al. 2018).

\section{RESULTS}

Differences in size-class distributions of Scarus trispinosus were observed between offshore and inshore reefs, with larger individuals being more common in offshore reefs and smaller individuals in inshore reefs (Fig. 2A). The smallest and largest specimens collected in the inshore reefs were $8.1 \mathrm{~cm}$ FL (10.3 g) and $41.8 \mathrm{~cm}$ FL (2035 g), respectively, with average $( \pm$ SD) FL and weight of $32 \pm 6.1 \mathrm{~cm}$ and $794 \pm 398 \mathrm{~g}$, whereas the smallest and largest specimens collected in the offshore reefs were $35 \mathrm{~cm}$ (975 g) and $55.9 \mathrm{~cm}$ (4955 g), respectively, with average FL and weight of $48.1 \pm 4.8 \mathrm{~cm}$ and $2675 \pm 849 \mathrm{~g}$. The sizes of the sampled specimens reflected the size class distribution within each location, with largesized individuals absent in the inshore reefs and small-sized individuals absent in the offshore reefs (Roos et al. 2016, 2019). The relationship between FL $(\mathrm{cm})$ and TW $(\mathrm{kg})$ was described by TW $=15 \times$ $10^{-6}(\mathrm{FL})^{3.11}$ (Fig. 2C).

\subsection{Age, growth, and mortality}

The specimen ages ranged from $0.3 \mathrm{yr}(8.1 \mathrm{~cm}$ FL) to $7 \mathrm{yr}$ (55.9 $\mathrm{cm}$ FL). Differences in age distributions were observed between locations, with older individuals being more common in offshore reefs and younger individuals being more common in inshore reefs (Fig. 2B). The average $( \pm \mathrm{SD})$ age of individuals was $3.2 \pm 1.1 \mathrm{yr}$ in inshore reefs, and $5 \pm 0.8 \mathrm{yr}$ in offshore reefs. $Z$ based on the linear age-based catch curve was $0.773 \mathrm{yr}^{-1}$ (95\% CI: 0.683-0.863) for the inshore population (Fig. 2B). The growth trajectory indicated rapid initial growth in the first $2 \mathrm{yr}$, with continuous growth sustained throughout 7 yr (Fig. 2D). Combining samples from both locations, the species reaches an asymptotic length $\left(L_{\infty}\right)$ of $71.3 \mathrm{~cm}$ FL, most likely at older ages than $7 \mathrm{yr}$. Further growth parameters were $0.16 \mathrm{yr}^{-1}(\mathrm{k})$ and $-0.8 \mathrm{yr}\left(t_{0}\right.$; Table 1).

\subsection{Reproduction}

A total of 90 gonads were processed histologically for assignment of sex and reproductive stages. These individuals ranged from 18.6 to $55.9 \mathrm{~cm}$ FL. All gonads were ovariform, with samples composed only of immature and regenerating mature females. Immature females had no evidence of prior spawning, small ovaries and lamellae were well-organized and filled with gonia and pre-vitellogenic oocytes, while regenerating mature females had small ovaries dominated by pre-vitellogenic oocytes with prior spawning indicated by the presence of muscle bundles and thick ovarian walls (Fig. 3). From the 90 gonads, 6 were considered as undetermined female, i.e. ovary contained gonia and pre-vitellogenic oocytes, but it 

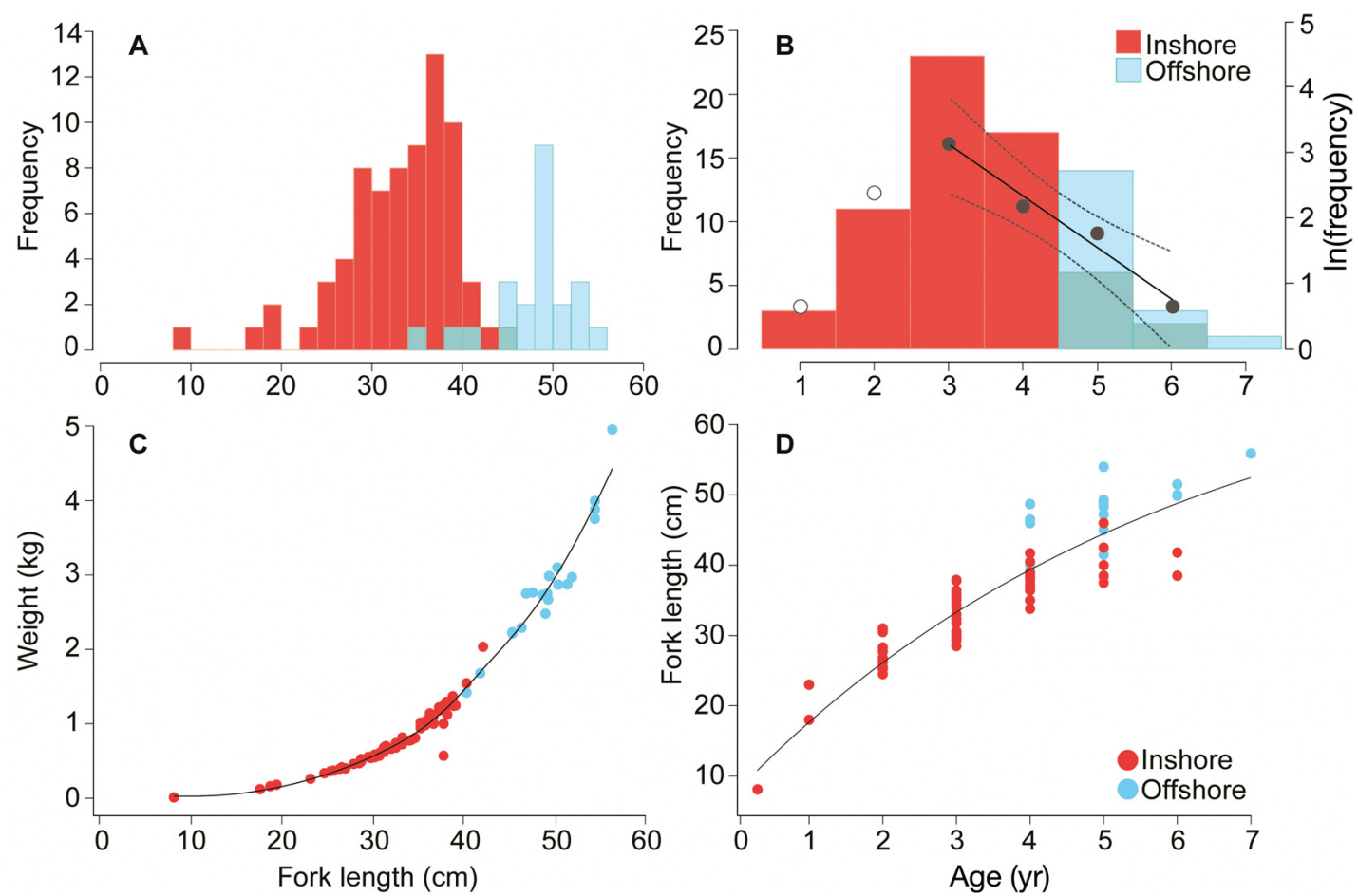

Fig. 2. (A) Length class distribution and (B) age frequency distribution; data points and linear regression line (with $95 \%$ confidence limits) represent the age-based catch curve for inshore samples derived from natural log-transformed catch at age values; open circles indicate age classes that are not fully recruited to the fishery. (C) Length-weight relationship described by TW $=15 \times 10^{-6}(\mathrm{FL})^{3.11}$, where TW is total weight and FL is fork length $\left(\mathrm{R}^{2}=0.93, \mathrm{~N}=85\right)$. (D) Von Bertalanffy growth curve fitted to length-at-age, $\mathrm{N}=80$

was not possible to determine if the individual had spawned previously or was immature.

All individuals from offshore reefs were mature females, while only $14 \%$ of individuals from inshore reefs were mature females. $L_{50}$ and $A_{50}$ were estimated at $39.2 \mathrm{~cm}$ FL (95\% CI: 38.2-40.2 cm) and $4.2 \mathrm{yr}$ (95\% CI: 4-4.4 yr), respectively, and length and age of $100 \%$ female maturation $\left(L_{100}\right.$ and $\left.A_{100}\right)$ were estimated at $51.6 \mathrm{~cm}$ FL (95\% CI: 48.3-54.9 cm) and 6.6 yr (95\% CI: 6-7.2 yr; Fig. 4, Table 1).

\section{DISCUSSION}

We provided an assessment of age-based and reproductive biology of Scarus trispinosus, an Endangered endemic species threatened by severe fishing pressure that resulted in a $\sim 50 \%$ decline in the population over the past $30 \mathrm{yr}$ (Padovani-Ferreira et al. 2012). We found differences in size class distributions, reproductive stages, and ages between inshore and offshore reefs, suggesting an ontogenetic variation in habitat use, with juveniles recruiting in shallow inner shelf reefs and early adults migrating to outer reef systems with increasing size (a pattern also described by Roos et al. 2019). Most of the fishing effort on this species is spatially localized in these inshore reefs, where about $9 \mathrm{t}$ of $S$. trispinosus are harvested annually and most individuals are captured between 22 and $36 \mathrm{~cm}$ (Roos et al. 2016), therefore below their estimated $L_{50}(39.2 \mathrm{~cm})$. While the age of female maturation $\left(A_{50}\right)$ of $S$. trispinosus was estimated at $4.2 \mathrm{yr}$, most parrotfish of the genus Scarus reach maturation earlier (1-3 yr;

Table 1. Summary of life-history trait estimates for Scarus trispinosus from Rio Grande do Norte state (this study) and the Abrolhos Bank (Freitas et al. 2019), Brazil. $L_{\infty}$ : asymptotic length; $k$ : growth coefficient; $t_{0}$, hypothetical age when length equals $0 ; L_{50}\left(L_{100}\right)$ : length at $50 \%(100 \%)$ sexual maturity; $A_{50}\left(A_{100}\right)$ : age at $50 \%(100 \%)$ sexual maturity; $Z$ : total mortality rate (inshore samples only). Associated $95 \%$ confidence intervals are presented in parentheses when available

\begin{tabular}{|lcc|}
\hline Trait & Rio Grande do Norte & Abrolhos Bank \\
\hline$L_{\infty}(\mathrm{cm})$ & $71.3(57.4,81.5)$ & $85.28(80.7,89.77)$ \\
$k\left(\mathrm{yr}^{-1}\right)$ & $0.16(0.10,0.22)$ & $0.14(0.12,0.16)$ \\
$t_{0}(\mathrm{yr})$ & $-0.80(-0.35,-1.25)$ & $0.16(-0.24,0.56)$ \\
$L_{50}(\mathrm{~cm})$ & $39.2(38.2,40.1)$ & $38.5(37.4,39)$ \\
$L_{100}(\mathrm{~cm})$ & $51.6(48.2,54.9)$ & 51 \\
$A_{50}(\mathrm{yr})$ & $4.2(4,4.4)$ & 4.45 \\
$A_{100}(\mathrm{yr})$ & $6.6(6,7.2)$ & 11 \\
$Z\left(\mathrm{yr}^{-1}\right)$ & $0.773(0.683,0.863)$ & 0.75 \\
\hline
\end{tabular}



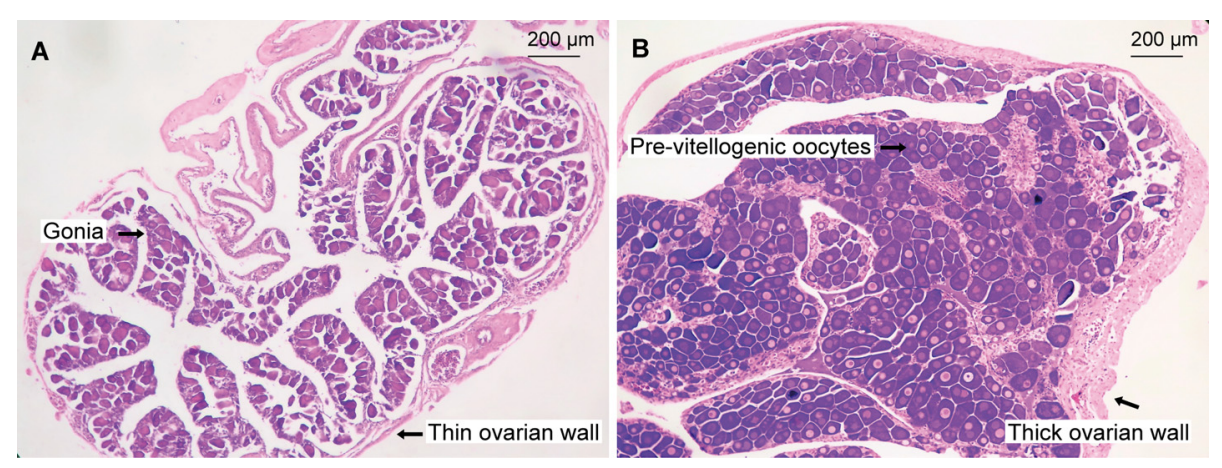

Fig. 3. Photomicrograph of a histological section of Scarus trispinosus ovaries: (A) immature female, (B) regenerating mature female
Taylor et al. 2014), highlighting the intrinsic vulnerability of $S$. trispinosus. Most of the individuals harvested by coastal fisheries are within the size and age range prior to full female maturation (Roos et al. 2016), which may have a considerably negative impact on population dynamics; therefore, the information provided here is critical to inform the urgent implementation of management actions to protect $S$. trispinosus.

Most parrotfishes are considered 'short-lived' with a life span between 5 and 23 yr (Choat et al. 1996, Taylor \& Choat 2014) compared with other roving herbivores such as surgeonfishes (Acanthuridae) that reach up to 40+ yr old (Choat \& Axe 1996). Evidence suggests that $S$. trispinosus may reach up to $22 \mathrm{yr}$ old and $86 \mathrm{~cm}$ TL on the Abrolhos Bank (Freitas et al. 2019), and $20 \mathrm{~kg}$ TW in Arraial do Cabo (RJ), southeast Brazil (Bender et al. 2014). This demonstrates that the species is relatively larger and longer-lived among parrotfishes, particularly those from the genus Scarus, which usually reach maximum ages between 5 and $15 \mathrm{yr}$ and maximum sizes around $40 \mathrm{~cm}$ TL (Choat et al. 1996, Taylor \& Choat 2014, Taylor et al. 2014). Here, the oldest $S$. trispinosus sampled was 7 yr $(\mathrm{N}=1)$, while most individuals were between 3 and $5 \mathrm{yr}(\mathrm{N}=60)$, indicating that the sampled populations were mainly composed of early-adults, especially in the inshore reefs where younger individuals were present. The absence of older $S$. trispinosus could be explained by differences in habitat use, whereby older individuals could be using deeper habitats (>50 m; Feitoza et al. 2005), which we were not able to sample due to logistical constraints. Although the life span of $S$. trispinosus in the studied region $\left(\sim 5^{\circ} \mathrm{S}\right.$; winter mean sea surface temperature [SST] of $26.7^{\circ} \mathrm{C}$ ) is likely to be greater than presented in this study, it is unlikely to be comparable to the population from the Abrolhos Bank $\left(\sim 17^{\circ} \mathrm{S}\right.$; winter-mean SST of $24.8^{\circ} \mathrm{C}_{\boldsymbol{i}}$ Met Office Hadley Centre's Sea Surface Temperature dataset; available from https://coastwatch. pfeg.noaa.gov/erddap/griddap/erdHadISST.graph;
Freitas et al. 2019). Maximum sizes and ages at lower latitudes are expected to be lower, since age-based demography of reef fishes varies with sea temperature (e.g. Choat et al. 2003, Robertson et al. 2005, Taylor \& Pardee 2017, Taylor et al. 2019). Despite potential differences in longevity between individuals in our study area and in the Abrolhos Bank, age and size of maturation were comparable between these regions (Table 1).

The population from the inshore reefs is mainly comprised of younger and immature females (i.e. $86 \%$ ), while the individuals sampled in the offshore reefs were all mature females in regenerating stages. Due to the absence of active males in the samples, it was not possible to confirm the pattern of sexual development of males. If the population contained males that have recruited from functionally active females, then protogynous hermaphroditism would be confirmed; otherwise, $S$. trispinosus could be a secondary gonochore, with all males being recruited from immature individuals with non-functional ovaries (Hamilton et al. 2008, Sadovy de Mitcheson \& Liu 2008). However, the complete absence of males in the sample gives considerable support for a monandric protogynous sexual pattern, given that no primary males were observed across all size classes in our study area. The presence of small and potentially primary males $\left(<L_{50}\right)$ in the Abrolhos Bank, however, suggests that $S$. trispinosus may have a diandric protogynous sexual pattern (Freitas et al. 2019), but further investigation is needed. The presence of inactive females in the population suggests that fish do not all spawn at the same times and/or locations, or not all females spawn in all years (Pears et al. 2006). The absence of both active females and males in the samples strongly suggests differentiation of habitat use by such individuals. Although larger-sized individuals from this study were collected in offshore reefs ( $22 \mathrm{~km}$ from the coast), the locations where they were collected were relatively shallow (between 8 and $12 \mathrm{~m}$ deep). S. trispinosus, 

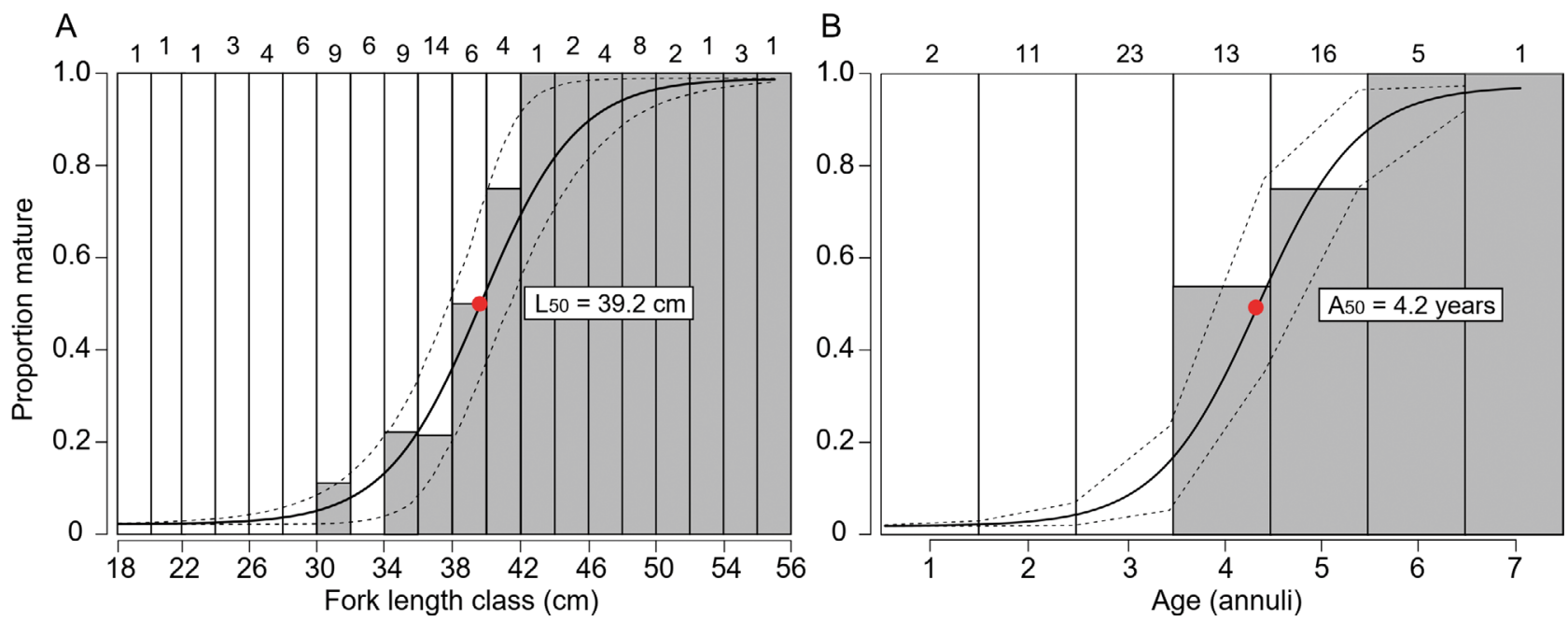

Fig. 4. Proportional frequencies of immature (white bars) and mature (grey bars) females of Scarus trispinosus (A) fork length class and (B) age class. Red dots indicate $50 \%$ maturity by size and age, respectively. Numbers above bars represent sample sizes. Solid lines represent best-fit models, dotted lines represent the associated $95 \%$ confidence intervals

however, was already recorded in deeper outer shelf reefs (between 50 and $60 \mathrm{~m}$ deep) of the same region (Feitoza et al. 2005), suggesting that deeper habitats may harbor even larger and older individuals. In the Abrolhos Bank, male $S$. trispinosus become more frequent in the population from age 8 onwards, with older individuals found mainly in offshore reefs composed of rhodolith beds between 24 and $65 \mathrm{~m}$ deep (Bastos et al. 2013, Freitas et al. 2019). In the present study, older age classes were probably under-sampled due to constraints in sampling deeper areas, which may explain the complete absence of males among the samples. However, because fishing has likely truncated larger individuals from the population, the probability of sampling males could have been greater if the population was not overfished. Juvenile individuals, in turn, use mainly the inshore reefs, indicating that the area may work as a nursery habitat for $S$. trispinosus. Even with the absence of males among the samples, our results are useful to guide size-based fisheries management and shed light on ontogenetic differentiation of habitat use by the species. These differences between inshore and offshore reefs are unlikely related to the temporal variation in our sampling effort, since they agree with the size class distribution previously described for these habitats based on both fishing data and underwater visual censuses (Roos et al. 2016, 2019). Additionally, these locations are relatively close to each other $(200 \mathrm{~km})$ and share similar abiotic conditions that could affect growth and maturation, such as temperature.

Considering $S$. trispinosus is a relatively long-lived species, $Z$ in the inshore reefs was high $\left(0.773 \mathrm{yr}^{-1}\right)$.
The population decline towards age 6 observed in the inshore reefs may result both from the emigration to offshore reefs and the sum of mortalities from various sources, including natural and fishery mortalities. However, given the scarcity of large-sized individuals and lower abundance of $S$. trispinosus in offshore reefs in this area (Roos et al. 2019), we expect that fishing mortality is high. Fishing effort focused on parrotfishes only occurs in the inshore reefs where commercial small-scale and recreational fisheries target $S$. trispinosus with the use of gillnets and spearguns (Roos et al. 2016). Although spearguns catch larger individuals (average size of $39.3 \mathrm{~cm}$ FL) compared to gillnets (average size of $28.6 \mathrm{~cm}$ FL; Roos et al. 2016), $80 \%$ of all individuals caught in the inshore reefs are below $L_{50}$ (i.e. $39.2 \mathrm{~cm}$ ). Although $S$. trispinosus is not a main target of the small-scale fishery in the offshore reefs because fishers preferably catch more valuable species when they fish further from the coast (e.g. Lutjanidae; see details in Damasio et al. 2015), recreational fishing occurs frequently in the offshore reefs, in which case $S$. trispinosus is among the main targets. Given a possible decline of snappers (Lutjanidae) and groupers (Serranidae), which are among the main targets in the offshore reefs (Damasio et al. 2015), it is likely that large-bodied parrotfish such as $S$. trispinosus will also become a more frequent target for commercial fisheries, as shifts in fishing targets are well known and documented in many regions (Pauly et al. 1998).

Shallow inshore and deeper offshore reefs are distinct with respect to $S$. trispinosus size class distribution and maturation schedules, as well as fishing pres- 
sure. Fishing has been occurring in the inshore reefs, where fisheries management is urgently needed. Our results provide useful guidelines to size-based fisheries management in the region, despite potential limitations related to the number of individuals and absence of males in the samples. The establishment of a minimum size limit at $L_{50}$ as a management strategy for $S$. trispinosus in this area would protect most immature individuals and decrease the catches by $80 \%$ (Roos et al. 2016). If well-regulated and enforced, spearguns may be more suitable fishing gears than gillnets with mesh sizes of 50 and $60 \mathrm{~mm}$ that are non-selective, and catch mostly immature individuals (Roos et al. 2016). In addition to size limits and changes in fishing gear, $S$. trispinosus populations would benefit from multiple and integrated management actions, including well enforced notake zones in the inshore reefs, catch quotas, and/or limited fishing season, as well as the ban on recreational fishing both in inshore and offshore reefs. If such measures are not well implemented, it may lead to lack of compliance and economic loss for fishers, who may eventually change fishing targets for other vulnerable species. Economic losses may critically compromise the opportunities for compliance (Carvalho et al. 2019) and represent a compelling point to get fishers involved and in agreement with any decision making process. Therefore, fishers' participation in decision making will be critical to ensure compliance (Lopes et al. 2013).

In 2014, for example, $S$. trispinosus was listed as endangered on the Brazilian Red List of Endangered Species (Decree No. 445), which banned fishing for the species, albeit with no enforcement. This measure has generated many protests by the fishers and an almost complete lack of compliance. Most recently, in 2018, fishing of $S$. trispinosus was regulated through the Brazilian National Recovery Plan for endangered species (Decree No. 59-B). This plan proposes spearguns as the only fishing gear allowed, a slot-size limit of catch between 39 and $63 \mathrm{~cm} \mathrm{TL}$, the ban on industrial and recreational fishing, and that fishing would only be allowed within multiple-use marine protected areas by authorized fishers. In fact, the inshore reefs from this study are located within a multiple-use marine protected area with specific fishing and no-take zones (Área de Proteção Ambiental Recifes de Coral - RN), so the proposed criteria could be applied if a proper enforcement is implemented, as poaching is currently frequent in the notake areas. Our results strongly suggest that the $S$. trispinosus population is overfished and confirm that the slot-size limit of 39-63 cm TL would be appropri- ate for managing $S$. trispinosus in our study area given the median size of maturity $(39.2 \mathrm{~cm})$, although individuals larger than $50 \mathrm{~cm}$ are uncommon in this area. Targeting medium-sized individuals (39-63 cm TL) could increase the fish population and even fishers' revenues (Reddy et al. 2013, Kindsvater et al. 2017). If the fishing pressure upon $S$. trispinosus is maintained at the current levels, this species may face another local ecological extinction as observed in southeastern Brazil (Bender et al. 2014). Managing fisheries of endangered species such as $S$. trispinosus is urgent and critical to aid recovery.

Acknowledgements. We are grateful to Professor Jorge Lins, Tiego Costa, Eudriano Costa, Lúcia Carvalho, and Sidney Roos for logistical support and to all fishers who supported us during fieldwork. A.R.C. thanks the Brazilian National Research Council (CNPq) for the productivity grant. This study was financed in part by the Coordenação de Aperfeiçoamento de Pessoal de Nível Superior Brasil - Finance Code 001, through a PhD scholarship awarded to N.C.R. The authors also acknowledge the Pró-Reitoria de Pós-Graduação of Universidade Federal do Rio Grande do Norte for supporting the publication fees. We thank 3 anonymous reviewers for their insightful comments on the manuscript.

\section{LITERATURE CITED}

Aswani S, Sabetian A (2010) Implications of urbanization for artisanal parrotfish fisheries in the Western Solomon Islands. Conserv Biol 24:520-530

*Bastos AC, Moura RL, Amado-Filho GM, D'Agostini DP and others (2013) Buracas: novel and unusual sinkhole-like features in the Abrolhos Bank. Cont Shelf Res 70:118-125

* Bellwood DR, Choat JH (1990) A functional analysis of grazing in parrotfishes (family: Scaridae): the ecological implications. Environ Biol Fishes 28:189-214

* Bellwood DR, Hoey AS, Hughes TP (2012) Human activity selectively impacts the ecosystem roles of parrotfishes on coral reefs. Proc R Soc B 279:1621-1629

Bender MG, Machado GR, Silva PJA, Floeter SR, MonteiroNeto C, Luiz OJ, Ferreira CEL (2014) Local ecological knowledge and scientific data reveal overexploitation by multigear artisanal fisheries in the southwestern Atlantic. PLOS ONE 9:e110332

Beverton RJH, Holt SJ (1957) On the dynamics of exploited fish populations. Chapman and Hall, London

Bonaldo RM, Hoey AS, Bellwood DR (2014) The ecosystem roles of parrotfishes on tropical reefs. Oceanogr Mar Biol Annu Rev 52:81-132

* Bozec YM, O'Farrell S, Bruggemann JH, Luckhurst BE, Mumby PJ (2016) Tradeoffs between fisheries harvest and the resilience of coral reefs. Proc Natl Acad Sci USA 113:4536-4541

* Brown-Peterson NJ, Wyanski DM, Saborido-Rey F, Macewicz BJ, Lowerre-Barbieri SK (2011) A standardized terminology for describing reproductive development in fishes. Mar Coast Fish 3:52-70

Carvalho AR, Pennino MG, Bellido JM, Olavo G (2019) Small-scale shrimp fisheries bycatch: a multi-criteria approach for data-scarse [sic] situations. Mar Policy (in press) www.doi.org/10.1016/j.marpol.2019.103613 
Choat JH, Axe LM (1996) Growth and longevity in acanthurid fishes; an analysis of otolith increments. Mar Ecol Prog Ser 134:15-26

Choat JH, Axe LM, Lou DC (1996) Growth and longevity in fishes of the family Scaridae. Mar Ecol Prog Ser 145:33-41

Choat JH, Robertson DR, Ackerman JL, Posada JM (2003) An age-based demographic analysis of the Caribbean stoplight parrotfish Sparisoma viride. Mar Ecol Prog Ser 246:265-277

Choat JH, Kritzer JP, Ackerman JL (2009) Ageing in coral reef fishes: Do we need to validate the periodicity of increment formation for every species of fish for which we collect age-based demographic data? In: Green BS, Mapstone BD, Carlos G, Begg GA (eds) Tropical fish otoliths: information for assessment, management and ecology. Springer, New York, NY, p 23-54

Comeros-Raynal MT, Choat JH, Polidoro BA, Clements KD and others (2012) The likelihood of extinction of iconic and dominant herbivores and detritivores of coral reefs: the parrotfishes and surgeonfishes. PLOS ONE 7:e39825

Damasio LMA, Lopes PFM, Guariento RD, Carvalho AR (2015) Matching fishers' knowledge and landing data to overcome data missing in small-scale fisheries. PLOS ONE 10:e0133122

Feitoza MF, Rosa RS, Rocha LA (2005) Ecology and zoogeography of deep reef fishes in northeastern Brazil. Bull Mar Sci 76:725-742

Floeter SR, Ferreira CEL, Gasparini JL (2007) Os efeitos da pesca e da proteção através de UC's marinhas: três estudos de caso e implicações para os grupos funcionais de peixes recifais no Brasil. In: Ministério do Meio Ambiente (org) Áreas aquáticas protegidas como instrumento de gestão pesqueira. Série Áreas Protegidas do Brasil, Vol 4. MMA, Brasília, p 183-199

Francini-Filho RB, Moura RL (2008) Dynamics of fish assemblages on coral reefs subjected to different management regimes in the Abrolhos Bank, eastern Brazil. Aquat Conserv 18:1166-1179

Freitas MO, Previero M, Leite JR, Francini-Filho RB, MinteVera CV, Moura RL (2019) Age, growth, reproduction and management of southwestern Atlantic's largest and endangered herbivorous reef fish (Scarus trispinosus Valenciennes, 1840). PeerJ 7:e7459

Hamilton RJ, Adams S, Choat JH (2008) Sexual development and reproductive demography of the green humphead parrotfish (Bolbometopon muricatum) in the Solomon Islands. Coral Reefs 27:153-163

Hamilton RJ, Almany GR, Stevens D, Bode M, Pita J, Peterson NA, Choat JH (2016) Hyperstability masks declines in bumphead parrotfish (Bolbometopon muricatum) populations. Coral Reefs 35:751-776

Hawkins JP, Roberts CM (2004a) Effects of fishing on sexchanging Caribbean parrotfishes. Biol Conserv 115:213-226

Hawkins JP, Roberts CM (2004b) Effects of artisanal fishing on Caribbean coral reefs. Conserv Biol 18:215-226

Kindsvater HK, Reynolds JD, Sadovy de Mitcheson Y, Mangel M (2017) Selectivity matters: rules of thumb for management of plate-sized, sex-changing fish in the live reef food fish trade. Fish Fish 18:821-836

* Lokrantz J, Nyström M, Norström AV, Folke C, Cinner JE (2010) Impacts of artisanal fishing on key functional groups and the potential vulnerability of coral reefs. Environ Conserv 36:327-337

Lopes PFM, Rosa EM, Salyvonchyk S, Nora V, Begossi A (2013) Suggestions for fixing top-down coastal fisheries

Editorial responsibility: Uwe Krumme,

Rostock, Germany management through participatory approaches. Mar Policy 40:100-110

Mumby PJ (2006) The impact of exploiting grazers (Scaridae) on the dynamics of Caribbean coral reefs. Ecol Appl 16:747-769

Ogle DH, Wheeler P, Dinno A (2018) FSA: Fisheries Stock Analysis. R package version 0.8.22. https://github.com/ droglenc/FSA

* Padovani-Ferreira B, Floeter SR, Rocha LA, Ferreira CEL and others (2012) Scarus trispinosus. The IUCN Red List of Threatened Species 2012: e.T190748A17786694. www.iucnredlist.org/details/190748/0 (accessed June 2019)

*Pauly D, Christensen V, Dalsgaard J, Froese R, Torres F Jr (1998) Fishing down marine food webs. Science 279: 860-863

* Pears RJ, Choat JH, Mapstone BD, Begg GA (2006) Demography of a large grouper, Epinephelus fuscoguttatus, from Australia's Great Barrier Reef: implications for fishery management. Mar Ecol Prog Ser 307:259-272

R Development Core Team (2015) R: a language and environment for statistical computing. R Foundation for Statistical Computing, Vienna

Keddy SMW, Wentz A, Aburto-Oropezad O, Maxey M, Nagavarapue S, Leslie HM (2013) Evidence of marketdriven size-selective fishing and the mediating effects of biological and institutional factors. Ecol Appl 23: 726-741

Robertson DR, Choat JH, Posada JM, Pitt J, Ackerman JL (2005) Ocean surgeonfish Acanthurus bahianus. II. Fishing effects on longevity, size and abundance? Mar Ecol Prog Ser 295:245-256

Koos NC, Pennino MG, Lopes PFM, Carvalho AR (2016) Multiple management strategies to control selectivity on parrotfishes harvesting. Ocean Coast Manag 134: $20-29$

Roos NC, Pennino MG, Carvalho AR, Longo GO (2019) Drivers of abundance and biomass of Brazilian parrotfishes. Mar Ecol Prog Ser 623:117-130

Kovira DPT, Gomes MP, Longo GO (2019) Underwater valley at the continental shelf structures benthic and fish assemblages of biogenic reefs. Estuar Coast Shelf Sci 224:245-252

* Sadovy de Mitcheson Y, Liu M (2008) Functional hermaphroditism in teleosts. Fish Fish 9:1-43

*Taylor BM, Choat JH (2014) Comparative demography of commercially important parrotfish species from Micronesia. J Fish Biol 84:383-402

Taylor BM, Pardee C (2017) Growth and maturation of the redlip parrotfish Scarus rubroviolaceus. J Fish Biol 90: 2452-2461

Taylor BM, Houk P, Russ GR, Choat JH (2014) Life histories predict vulnerability to overexploitation in parrotfishes. Coral Reefs 33:869-878

Taylor BM, Trip EDL, Choat JH (2018) Dynamic demography: investigations of life-history variation in the parrotfishes. In: Hoey AS, Bonaldo RM (eds) Biology of parrotfishes. CRC Press, Boca Raton, FL, p 69-98

* Taylor BM, Choat JH, DeMartini EE, Hoey AS and others (2019) Demographic plasticity facilitates ecological and economic resilience in a commercially important reef fish. J Anim Ecol 88:1888-1900

Wickham H (2016) ggplot2: Elegant graphics for data analysis. Springer-Verlag, New York, NY. https://ggplot2.tidyverse.org

Submitted: September 9, 2019; Accepted: December 23, 2019 Proofs received from author(s): March 20, 2020 